\title{
Appendix 2: Instruction for the Imperial and Royal Astronomer Maximilian Hell, S.J.
}

1. The imperial and royal astronomer is to set in place a perfect arrangement for all the instruments pertaining to this study and make sure they are calibrated when necessary and well taken care of. ${ }^{1}$

2. It will be his responsibility to make daily observations of the trajectories of the planets, thereby taking heed of the journals of observations that were begun by, and continued through many years by the Gentleman de Marinoni, and to enter his observations meticulously in suitable notebooks.

3. The populace is to be urged and invited by way of published announcements or posters placed on gates to make observations of eclipses, occultations of stars, comets, and other unusual astronomical phenomena.

4. In order to promote the honor of this capital and its university, and to steer it toward the common good, the imperial and royal astronomer shall entertain a perpetual scientific correspondence with all the famous observatories abroad, and in so doing make sure that all observations that are necessary for the advancement of geography be communicated to this observatory by the foreign ones, and that no observations of the kind that other astronomers are eager to receive, shall be neglected by him.

5. All supervision of the calendars is bestowed and laid upon him. This responsibility will not only consist in making sure that everything that may originate from the superstition of the ancients and the multitude, or from the unfounded astrology, on weather, medications, bloodletting, growth of plants, or human coincidences, shall be completely avoided: he is also to edit an astronomical calendar every year and to publish it in time.

6. The above-mentioned is given responsibility, besides mechanical, practical, and calculatory astronomy, also for the courses in mechanics, which he shall deliver in the German vernacular at a suitable time every Sunday in the philosophical

1 This 7-point list is the formal job instruction Hell received on his appointment as court astronomer, in September 1755. Ernennung Maximilian Hells zum k.k. Astronomen. Beilage: Instruction. Für dem Kaiser. Königl. Astronomen Maximilianum Hell S.J. UAw, Universitätskonsistorium, CA 1.2.102 (translated from the German). On this document, see the discussion in Chapter 2 above. 
lecture hall, and illustrate by means of mechanical experiments, and he is to announce these courses by way of posters of invitation in advance.

7. He shall report every week to the director of philosophy about all his observations and scientific correspondence, and he shall inform the director, to whom he is responsible in all matters relating to his office, about his further activities, on what subject matters are to be included in his calendars and mechanics courses, and what works he is going to publish. 